\title{
A FIELD TEST FOR THE CUES OF DIAPAUSE IN A FRESHWATER COPEPOD
}

\author{
Nelson G. Hairston, Jr., Theresa A. Dillon, and Bart T. De Stasio, Jr. ${ }^{2}$ \\ Section of Ecology and Systematics, Division of Biological Sciences, Cornell University, \\ Ithaca, New York 14853 USA
}

\begin{abstract}
The freshwater calanoid copepod Diaptomus sanguineus switches each year in spring from making eggs that hatch immediately to making diapausing eggs that rest in lake sediments for an extended period. In lakes and ponds containing planktivorous fish, the timing of the switch is highly consistent between years and comes at the theoretically optimal time (late March) to avoid intense summer predation. In fishless ponds the timing comes 1-2 mo later. We investigate here the environmental cues used by the copepods to time the switch to diapause. Through the use of both field and laboratory manipulations, we show that temperature and photoperiod play central roles as diapause stimuli. A field manipulation of fish density failed to reveal either a direct induction of diapause or any more subtle effects of fish occurrence on diapause timing. The copepods made immediately hatching eggs under short-day or low-temperature conditions, and diapausing eggs under long days or high temperatures. There appears to be variation between individuals in their responses to temperature and photoperiod so that similar diapause phenologies are produced by different sensitivities to the environmental cues.
\end{abstract}

Key words: Calanoida; Copepoda; cues; diapause; dormancy; planktivorous fish; predators; photoperiod; temperature.

\section{INTRODUCTION}

Diapause permits animals to survive harsh periods in the environment during which fitness gained via survival and reproduction in the active state falls below the probability of survival in dormancy (Levins 1969, Cohen 1970). This fitness transition usually occurs well before the environment actually changes. In most organisms diapause is limited to one or a few life history stages, and the optimum time to begin diapause comes a generation or more prior to the onset of harsh conditions (Taylor 1980, Hairston and Munns 1984). As a result, real-time cues to environmental change may well come too late to permit optimum fitness response. It is presumably for this reason that a great many animals begin diapause in response to token stimuli (sensu Tauber et al. 1986) that do not directly influence fitness, but that are reliable predictors of future conditions. Photoperiod is the most prevalent of these stimuli (Beck 1980, Flint et al. 1981, Tauber et al. 1986), but other factors, such as temperature, crowding, and food limitation (Tauber et al. 1986) may also be involved.

\section{Life history of Diaptomus sanguineus}

The freshwater copepod Diaptomus sanguineus is active in ponds and small lakes in winter and spring. It makes immediately hatching eggs in winter and shifts to making diapausing eggs in spring each year. Previous

\footnotetext{
${ }^{1}$ Manuscript received 14 June 1989; revised 28 November 1989; accepted 10 January 1990.

${ }^{2}$ Present address: Center for Limnology, University of Wisconsin, Madison, Wisconsin 53706 USA.
}

research has shown that, in habitats with planktivorous fish, the timing of the switch to production of diapausing eggs is an adaptation to avoid the seasonal increase in fish predation as water temperature rises (Hairston and Munns 1984, Hairston and Walton 1986, Hairston 1987). Photoperiod is a good predictor of this kind of seasonality, and Hairston and Olds $(1986,1987)$ have demonstrated in laboratory experiments that animals reared in winter conditions make immediately hatching eggs, whereas those reared in summer conditions make diapausing eggs.

Two observations suggest, however, that one or more additional environmental cues are involved in stimulating the annual switch to production of diapausing eggs in this copepod. First, the photoperiod response observed in the laboratory, while consistent in direction with the field pattern, is much more gradual (Hairston and Olds 1986). In the laboratory, $95 \%$ of the copepods switched egg type between photoperiods of 8.5:15.5 and 14.8:9.2 L:D, whereas in the field the same fraction switches between only 11.2:12.8 and 13.0:11.0 L:D. One might expect from consideration of the potential effects of random environmental variation that response in the field would be less precise than that in controlled laboratory conditions. The opposite trend observed here indicates that some other cue, present in the field but omitted from the laboratory, is involved. Temperature is a likely candidate because in these small lakes it is nearly as reliable as photoperiod as an indicator of time of year. The warming and cooling of the water is highly repeatable between years (Black and Hairston 1988). Furthermore, temperature has frequently been shown to be an important stimulus 
for diapause timing in copepods (Watson and Smallman 1971, Marcus 1982) as well as other organisms (Beck 1980, Tauber et al. 1986). Second, populations of $D$. sanguineus living in the presence of fish switch to production of diapausing eggs substantially earlier in the year than do populations living where fish are absent. Specifically, diapause in populations of $D$. sanguineus living in small permanent or semipermanent lakes with fish comes 1-2 mo earlier than it does in populations living in fishless temporary ponds (Hairston and Olds 1984, Hairston et al. 1985, Hairston and Walton 1986). One might therefore expect that some direct indicator of predation regime (either chemical or physical and hereafter called "fish factor") could be involved in cuing dormancy. The recent proliferation of examples among zooplankton of chemically induced morphological and behavioral defenses against predators (e.g., Gilbert 1966, Havel 1980, Kerfoot 1987, Dodson 1988) lends plausibility to this hypothesis.

Virtually all experimental studies of diapause stimuli carried out to date have been done in the laboratory because it provides an easily controlled environment for unambiguous manipulation. Furthermore, field manipulations are logistically much more involved. Still, laboratory-derived results may not be directly applicable to natural population events because the cues studied are never perfectly duplicated in the laboratory, and because in nature multiple cues may interact to produce a particular response. Here we report the results of a field experiment in which both temperature and occurrence of fish differed between subpopulations of $D$. sanguineus. In addition, temperature effects were tested directly in a more typical laboratory setting. The results show a consistent, very strong effect of temperature on diapause timing, but no apparent ability of the copepods to alter their phenology in response to the presence of predatory fish.

\section{METHODS}

\section{Pond-division experiments in the field}

Little Bullhead Pond, Rhode Island is a small, semipermanent body that, over the period of study, has contained water continuously except during a severe drought in 1981. Prior to the drought the pond contained planktivorous sunfish (Lepomis auritus), but these were killed when the pond dried. In July 1985 an impervious vinyl-fiberglass barrier was installed in the pond dividing it into four quadrants (northeast, northwest, southeast, and southwest) of equal water volume. The curtain is attached to floats at the surface and anchored at the bottom by a chain in a sleeve, buried 15-20 cm deep in the sediments. There is a $1 / 2-\mathrm{cm}$ mesh net rising $45 \mathrm{~cm}$ above the surface floats to prevent fish from jumping over. In July and August 1986, 700 sunfish (bluegill, L. macrochirus and pumpkinseed, L. gibbosus) were introduced into each of the NW and SE quadrants while the NE and SW quadrants
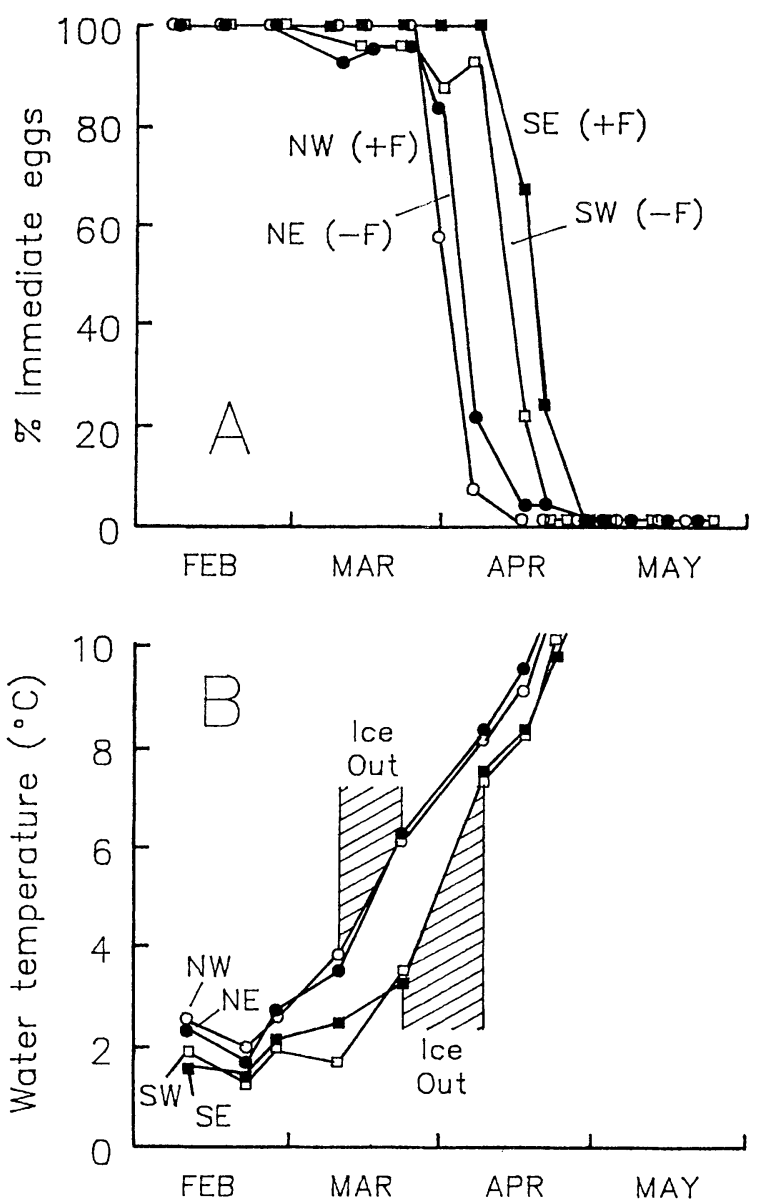

Fig. 1. (A) The percentage of female Diaptomus sanguineus making immediately hatching eggs (as opposed to diapausing eggs) in each of the four quadrants in Little Bullhead Pond in 1987. Two quadrants contained fish (NW and SE) and two were fishless (NE and SW). (B) Mean water column temperature in each of the four quadrants in Little Bullhead Pond during 3 mo in 1987. The intervals between sampling dates when ice cover ended are indicated for the northern and southern quadrants as "Ice Out."

were maintained fish-free. This density of introduced fish is effectively the same $\left(2 \mathrm{fish} / \mathrm{m}^{3}\right)$ at which sunfish occurred before the drought.

The copepods in Little Bullhead Pond switch to making diapausing eggs in March or April (Fig. 1B). Because fish were introduced in mid- to late summer, the copepods in the fish-addition quadrants were exposed to the presence of fish for an extended period (two generations, Hairston and Munns 1984, Braner and Hairston 1989) without any selection on diapause timing having taken place. The two fishless quadrants serve as controls for this treatment. Thus, if $D$. sanguineus can respond to some unknown fish factor by altering its diapause response, we would expect copepods in the quadrants with fish to switch to making diapausing eggs earlier than those in fishless quadrants. This test could be made only once because any differences ob- 
served between quadrants after the 1 st yr might also be attributable to selection response.

The south side of Little Bullhead Pond is shaded during winter by a tree-covered hill. Ice-out in spring always begins on the north side of the pond, which is exposed to direct sunlight. After the pond was divided into quadrants the ice melted from the north quadrants nearly 2 wk earlier than it did from the south quadrants. A field test for temperature as a diapause stimulus was not originally part of the rationale for running the experiment as we did, but the temperature distinction that developed between the two north and the two south quadrants provided an opportunity to look for such an effect.

Twenty-four live ovigerous female $D$. sanguineus were collected weekly from each quadrant throughout their reproductive period. Each female with eggs was isolated in a $15-\mathrm{mL}$ tissue culture well containing 25 $\mu \mathrm{m}$ mesh filtered pond water, placed in a controlled environment chamber (12:12 L:D and $15^{\circ} \mathrm{C}$, although photoperiod and temperature do not influence dormancy after an egg is produced, see Hairston and Olds 1984), and monitored for a minimum of $2 \mathrm{wk}$ for egg hatching. Female $D$. sanguineus make clutches of only one egg type at a time; mixed clutches are never seen (Hairston and Olds 1984). Clutches of immediately hatching eggs generally hatch within $1 \mathrm{wk}$ of being laid, and those that had not hatched within 2 wk were assumed to be diapausing eggs. Mortality of isolated eggs is minimal, and this method has been shown to be $95 \%$ effective in determining egg type (Hairston and Olds 1984). Water temperatures were taken at three depths in each quadrant on each sampling date.

\section{Laboratory experiments on temperature effects}

Ovigerous female $D$. sanguineus were collected from Bullhead Pond in early March 1988, when all individuals were still carrying immediately hatching eggs (Hairston 1987). Their eggs were hatched in the laboratory and immatures were reared in controlled environment chambers in glass-fiber-filtered Bullhead Pond water. Developing animals were fed ad libitum laboratory cultured Chlamydomonas reinhardii and Euglena gracilis. The chambers were set at 14.5:9.5 L:D. At this photoperiod (which corresponds to the 2nd wk in May) virtually none of the animals in the field, and only $\approx 10 \%$ of animals reared in the laboratory, make immediately hatching eggs (Hairston and Olds 1986).

Newly hatched copepods from the field-collected ovigerous females were divided into three groups. One group was reared at $4^{\circ} \pm 1^{\circ}$, a typical winter water temperature. A second group was reared at $11^{\circ} \pm 1^{\circ}$, a typical post-switch-date pond temperature. Individuals in a third group were reared at $4^{\circ}$ until they reached the fifth copepodid stage, at which time they were transferred to $11^{\circ}$ for maturation in the sixth copepodid stage (to test whether adults or earlier instars are the stage sensitive to the environmental cue). In each treatment, when females matured, they were isolated in $125-\mathrm{mL}$ jars with one or two males reared under the same conditions. When a clutch of eggs was produced, it was isolated in a $15-\mathrm{mL}$ plastic tissue culture well and monitored to determine egg type as described above. Thus copepods were assayed for the influences of continuous cold temperature, continuous warm temperature, or a rapid pre-reproduction temperature switch on type of egg produced.

\section{RESULTS}

\section{Pond-division experiments in the field}

There was no discernible effect of the presence or absence of fish on the timing of the switch to production of diapausing eggs (Fig. 1A). Copepods in the quadrants containing fish (southeast and northwest) showed no tendency to switch earlier in the year than those in the fishless quadrants. In contrast, there was a marked north-south difference in timing of diapause with copepods in the north switching more than a week earlier, on average, than those in the south. The difference in timing of ice-out is reflected in the water temperature of the quadrants (Fig. 1B). In 1987, the north quadrants were first recorded as ice free on the 24 March sampling date, while the south quadrants were first ice free on 7 April. In each case ice-out was accompanied by a marked water temperature increase from $3.5^{\circ}$ to $\approx 6^{\circ}$ or $7^{\circ} \mathrm{C}$, and followed a week later by the switch to production of diapausing eggs (at $\left.7^{\circ}-8^{\circ}\right)$.

\section{Laboratory experiments on temperature effects}

In controlled laboratory environments there was a strong effect of temperature on type of egg produced by $D$. sanguineus (Table 1 ). The effect appears to act more than a short time before the period of egg production, because the difference observed in proportion of females making immediately hatching eggs when reared at a constant $4^{\circ}$ compared with those reared at $4^{\circ}$ and switched to $11^{\circ}$ just before reproducing is only modest and not statistically significant $(.1>P>.05)$. Female copepods reared all or most of their lives at $4^{\circ}$ predominantly made clutches of immediately hatching eggs, whereas those reared entirely at $11^{\circ}$ made predominantly diapausing eggs. The result is particularly striking given that the photoperiod used represented one well into the season when copepods in the field make diapausing eggs.

\section{Discussion}

We found no evidence that predator presence or absence acts as a stimulus determining the timing of diapause in Diaptomus sanguineus. While it has been important to test the hypothesis that some unknown fish factor might act across generations to influence diapause timing, it is not necessarily surprising that no strong effect exists. The postulated indirect pathway of 
induction would require that a female detect the presence of fish in the water and place some nongenetic chemical into her eggs that carries information about what she detected. The chemical would have to survive through hatching, 12 instar molts, and a 50-fold increase in body mass before being expressed as a tendency in the offspring to respond differently to photoperiod and temperature than did their parents. Unlike the present situation, virtually all examples of nongenetic transfer of maternal traits to offspring involve characters related to nutrition, such as body size, growth rate, and survival (Falconer 1981, Lynch and Ennis 1983). Fish-killing droughts of the kind seen in Little Bullhead Pond (Hairston and Walton 1986) may be rare events, and evidence for local adaptation to conditions prevailing in specific ponds (Hairston and Olds 1984, Hairston et al. 1985) suggests that phoretic transfer of individuals between pond types is also infrequent. Thus selection for ability to respond to fish factor may be weak. As always, however, it is somewhat futile to speculate about why a particular adaptation has not appeared.

It is important to note that $D$. sanguineus cannot be responding to either temperature or fish factor as direct indicators of seasonal changes in fish activity. The annual switch to diapause occurs very close to the theoretically optimum date for avoiding the annual increase in predatory mortality (Hairston and Munns 1984, Hairston 1987), but this comes more than one generation before the spring increase in fish feeding activity. (Copepods switching later would make offspring that would grow up only to be consumed before reproducing.) It is plausible that because water temperature in early spring generally correlates well with water temperature later in the year, it could serve as a reliable predictor of the timing of future predation. It is improbable, however, that fish factor could act as anything but a binary cue to either the presence or absence of these predators. Whatever fish-produced cue might be present in the water at the time that the copepods switch egg type would be very unlikely to hold information about the precise timing of a predation increase more than a month later in the season. Hairston and Olds (1984) tested one aspect of this hypothesis by transferring reproducing females between a pond with fish and a temporary one without. They showed that individual copepods did not respond to the presence or absence of fish and adjust diapause timing accordingly, this despite later demonstration that individuals could be induced in the laboratory to alter egg type by changing photoperiod (Hairston and Olds 1987). This simpler mechanism of fish factor inducing reproducing females to make an immediate adjustment in egg type may be lacking because individual lineages rarely experience a switch in predator occurrence.

In contrast to the lack of predator effect, there is strong evidence that temperature plays a very impor-
TABLE 1. Numbers and percentages of female Diaptomus sanguineus making immediately hatching and diapausing eggs in response to one of three rearing-condition treatments.*

\begin{tabular}{|c|c|c|c|c|c|}
\hline \multirow[b]{2}{*}{$\begin{array}{l}\text { Treat- } \\
\text { ment }\end{array}$} & \multicolumn{2}{|c|}{$\begin{array}{l}\text { Number of } \\
\text { Females }\end{array}$} & \multirow{2}{*}{$\begin{array}{l}\% \text { im- } \\
\text { medi- } \\
\text { ately } \\
\text { hatch- } \\
\text { ing } \\
\text { clutches }\end{array}$} & \multirow[b]{2}{*}{$\chi^{2}$} & \multirow[b]{2}{*}{$P$} \\
\hline & $\begin{array}{l}\text { Imme- } \\
\text { diately } \\
\text { hatch- } \\
\text { ing }\end{array}$ & $\begin{array}{c}\text { Dia- } \\
\text { pausing }\end{array}$ & & & \\
\hline $\begin{array}{l}4^{\circ}-4^{\circ} \\
4^{\circ}-11^{\circ}\end{array}$ & $\begin{array}{l}42 \\
49\end{array}$ & $\begin{array}{r}8 \\
22\end{array}$ & $\begin{array}{l}84 \\
69\end{array}$ & 3.53 & NS \\
\hline $\begin{array}{l}4^{\circ} \text { total } \\
11^{\circ}-11^{\circ}\end{array}$ & $\begin{array}{l}91 \\
13\end{array}$ & $\begin{array}{r}30 \\
114\end{array}$ & $\begin{array}{l}75 \\
10\end{array}$ & 107.4 & $\ll .001$ \\
\hline
\end{tabular}

* Treatments: continuous rearing at $4^{\circ} \mathrm{C}\left(4^{\circ}-4^{\circ}\right)$, rearing from egg to penultimate instar at $4^{\circ}$ followed by maturation and mating at $11^{\circ}\left(4^{\circ}-11^{\circ}\right)$, and continuous rearing at $11^{\circ}\left(11^{\circ}-\right.$ $11^{\circ}$ ). All treatments were exposed to a 14.5:9.5 L:D photoperiod. Results of $4^{\circ}-4^{\circ}$ and $4^{\circ}-11^{\circ}$ treatments do not differ statistically and so are pooled here ( $4^{\circ}$ total) for comparison with $11^{\circ}-11^{\circ}$.

tant role in setting diapause timing in D. sanguineus. The study carried out in controlled environment chambers shows that a temperature difference of at most $7^{\circ} \mathrm{C}$ $\left(4^{\circ}-11^{\circ}\right)$ has a marked effect on photoperiod response. Observations from the pond division experiment are consistent with these laboratory results. Photoperiod was identical at all quadrants, yet copepods living in those that warmed later in the spring exhibited a distinct delay in the switch to making diapausing eggs. Indeed, the temperature range over which the switch occurred in the field ( $6^{\circ}-9^{\circ}$, Fig. 1B), is consistent between quadrants and falls within the range showing a strong effect in the laboratory $\left(4^{\circ}-11^{\circ}\right)$.

Temperature is known to play an important role as an environmental cue in the initiation of dormancy in a diversity of organisms including protists (Sandgren 1988), plants (Silvertown 1982), and insects (Beck 1980). Among the insects, a few groups have been shown to respond directly to temperature cues alone, but in the great majority of species temperature effects appear as modifications of diapause responses to photoperiod stimuli (Tauber et al. 1984, 1986). In agreement with patterns seen in insects, photoperiod cues have been documented for a number of zooplankton taxa including rotifers (Gilbert 1974), cladocerans (Stross and Hill 1965, Parker 1966, Stross 1969, Ferrari and Hebert 1982), and copepods (Spindler 1971, Watson and Smallman 1971, Marcus 1980, Hairston and Olds 1986), as have other cues such as food quality and population density (e.g., Banta 1939, Stross and Hill 1965, Gilbert 1974, 1977, D'Abramo 1980, Walton 1985). However, whereas temperature generally plays a role second only to photoperiod in diapause induction in terrestrial insects (Tauber et al. 1986), its role for zooplankton is less consistent. For example, there are very few reports (e.g., Hino and Hirano 1984) of effects of temperature on production of mictic females (and therefore production of diapausing eggs) among 
the Rotifera, even though such effects have been investigated in several instances (Gilbert 1974, 1977, Snell 1986). Among the Cladocera, subtle temperature effects on male production (leading to fertilization of diapausing eggs) were reported for Moina macropa by Brown and Banta (1932), though in this species, temperature was found to be much less important than crowding or abundance of food (Banta 1939). Temperature plays only a modest role in modifying photoperiod and crowding responses in Daphnia pulex (Stross 1969, 1987). On the other hand, temperature appears to be relatively important in diapause timing for the Copepoda. Among cyclopoid copepods, which diapause as immature copepodids or adults (Spindler 1971) rather than in the egg stage, there is a marked effect of temperature on the fraction of individuals that become dormant (Watson and Smallman 1971). For calanoid copepods, diapause occurs principally in the egg stage (Hutchinson 1967, Grice and Marcus 1981; oceanic Calanus are the only potential exceptions, Conover 1988). In every case investigated, temperature has been found to have a significant effect on diapause induction, including an effect on six freshwater species of Diaptomus (Champeau 1970, Walton 1985, present example), as well as two marine species (Johnson 1979, Marcus 1982).

Our data for Diaptomus sanguineus are consistent with what would seem to be a developing pattern. Copepods use temperature as an important cue for diapause, whereas most members of the other major groups of macrozooplankton, at least in freshwater, do not. What might be the reason for this? Two observations are important in considering the value of temperature as a stimulus in these organisms. First, copepods have generation times that are substantially longer than those characteristic of cladocerans and rotifers (Allan 1976, Allan and Goulden 1980). Second, at least in the examples studied to date, copepods typically enter diapause at a distinct transition of seasons (spring warming or fall cooling) and apparently to avoid seasonally predictable catastrophes such as pond drying (Champeau 1970, Hairston et al. 1985), predator activity (Strickler and Twombly 1975, Nilsson 1980, Hairston 1987), or cold temperatures (Marcus 1982). Cladocerans and rotifers, on the other hand, very often respond to events that are less temporally reliable, specifically food limitation and crowding (Banta 1939, Slobodkin 1954, Gilbert 1977). Whereas water temperature may be a serviceable predictor of seasonally driven environmental conditions occurring several weeks in the future, it is a much less reliable (or even uncorrelated) cue for more short-term events.

\section{ACKNOWLEDGMENTS}

We thank G. T. Epp, K. D. Hambright, W. G. Sprules, S. F. Tjossem, and two referees for their comments on the manuscript, S. Beck for a stimulating discussion of the data, and R. P. Clark and J. E. O'Brien for permitting us access to the study sites. The Department of Zoology, University of Rhode
Island, generously provided research space. The research was supported by National Science Foundation grant BSR8516724.

\section{Literature Cited}

Allan, J. D. 1976. Life history patterns in zooplankton. American Naturalist 110:165-180.

Allan, J. D., and C. E. Goulden. 1980. Some aspects of reproductive variation among freshwater zooplankton. Pages 388-410 in W. C. Kerfoot, editor. Evolution and ecology of zooplankton communities. University Press of New England, Hanover, New Hampshire, USA.

Banta, A. M. 1939. Studies on the physiology, genetics, and evolution of some Cladocera. Paper Number 39, Department of Genetics, Carnegie Institution of Washington, Washington, D.C., USA.

Beck, S. 1980. Insect photoperiodism. Academic Press, New York, New York, USA.

Black, R. W., and N. G. Hairston, Jr. 1988. Predator driven changes in community structure. Oecologia (Berlin) 77:468479.

Braner, M., and N. G. Hairston, Jr. 1989. From cohort data to life table parameters via stochastic modeling. In $\mathrm{L}$. McDonald, B. Manly, J. Lockwood, and J. Logan, editors. Measurement and analysis of insect populations. Lecture Notes in Statistics 55:81-92.

Brown, L. A., and A. M. Banta. 1932. Control of sex in Cladocera. VII: Male production in relation to temperature. Physiological Zoology 5:218-229.

Champeau, A. 1970. Etude de la vie latent chez les Calanoids (Copepodes) characteristiques des eaux temporaires de Basse-Provence. Annales de la Faculte des Sciences de Marseille 44:155-189.

Cohen, D. 1970. A theoretical model for the optimal timing of diapause. American Naturalist 104:389-400.

Conover, R. J. 1988. Comparative life histories in the genera Calanus and Neocalanus in high latitudes of the northern hemisphere. Hydrobiologia 167/168:127-142.

D'Abramo, L. R. 1980. Ingestion rate decrease as the stimulus for sexuality in populations of Moina macrocopa. Limnology and Oceanography 25:422-429.

Dodson, S. I. 1988. The ecological role of chemical stimuli for the zooplankton: predator avoidance behavior in Daphnia. Limnology and Oceanography 33:1431-1439.

Falconer, D. S. 1981. Introduction to quantitative genetics. Second edition. Longman, London, England.

Ferrari, D. C., and P. D. N. Hebert. 1982. The induction of sexual reproduction in Daphnia magna: genetic differences between arctic and temperate populations. Canadian Journal of Zoology 60:2143-2148.

Flint, A. P. F., M. B. Renfree, and B. J. Weir. 1981. Embryonic diapause in mammals. Journal of Reproduction and Fertility, Supplement 29.

Gilbert, J. J. 1966. Rotifer ecology and embryological induction. Science 151:1234-1237.

1974. Dormancy in rotifers. Transactions of the American Microscopical Society 93:490-513.

- 1977 . Mictic-female production in monogonont rotifers. Archiv für Hydrobiologie, Beiheft 8:142-155.

Grice, G. D., and N. H. Marcus. 1981. Dormant eggs of marine copepods. Annual Reviews of Oceanography and Marine Biology 19:125-140.

Hairston, N. G., Jr. 1987. Diapause as a predator-avoidance adaptation. Pages 281-290 in W. C. Kerfoot and A. Sih, editors. Predation: direct and indirect impacts on aquatic communities. University Press of New England, Hanover, New Hampshire, USA.

Hairston, N. G., Jr., and W. R. Munns, Jr. 1984. The timing of copepod diapause as an evolutionarily stable strategy. American Naturalist 123:733-751.

Hairston, N. G., Jr., and E. J. Olds. 1984. Population dif- 
ferences in the timing of diapause: adaptation in a spatially heterogeneous environment. Oecologia (Berlin) 61:42-48.

Hairston, N. G., Jr., and E. J. Olds. 1986. Partial photoperiodic control of diapause in three populations of the freshwater copepod Diaptomus sanguineus. Biological Bulletin (Woods Hole) 171:135-142.

Hairston, N. G., Jr., and E. J. Olds. 1987. Population differences in the timing of diapause: a test of hypotheses. Oecologia (Berlin) 71:339-344.

Hairston, N. G., Jr., E. J. Olds, and W. R. Munns, Jr. 1985. Bet-hedging and environmentally cued diapause strategies of diaptomid copepods. Internationale Vereinigung für theoretische und angewandte Limnologie, Verhandlungen 22:3170-3177.

Hairston, N. G., Jr., and W. E. Walton. 1986. Rapid evolution of a life history trait. Proceedings of the National Academy of Sciences (USA) 83:4831-4833.

Havel, J. E. 1980. Predator-induced defenses: a review. Pages 263-278 in W. C. Kerfoot and A. Sih, editors. Predation: direct and indirect impacts on aquatic communities. University Press of New England, Hanover, New Hampshire, USA.

Hino, A., and R. Hirano. 1984. Relationship between water temperature and bisexual reproduction rate in the rotifer Brachionus plicatilis. Bulletin of the Japanese Society of Scientific Fisheries 50:1481-1485.

Hutchinson, G. E. 1967. A treatise on limnology. Volume 2. John Wiley and Sons, New York, New York, USA.

Johnson, J. K. 1979. Effects of temperature and salinity on production and hatching of dormant eggs of Acartia californiensis (Copepoda) in an Oregon estuary. United States National Marine Fisheries Service Fishery Bulletin 77:567584.

Kerfoot, W. C. 1987. Translocation experiments: Bosmina responses to copepod predation. Ecology 68:596-610.

Levins, R. 1969. Dormancy as an adaptive strategy. Symposia of the Society of Experimental Biology 23:1-10.

Lynch, M., and R. Ennis. 1983. Resource availability, maternal effects, and longevity. Environmental Gerontology 18:147-165.

Marcus, N. H. 1980. Photoperiodic control of diapause in the marine calanoid copepod Labidocera aestiva. Biological Bulletin (Woods Hole) 159:311-318.

1982. Photoperiodic and temperature regulation of diapause in Labidocera aestiva (Copepoda: Calanoida). Biological Bulletin (Woods Hole) 162:45-52.

Nilsson, J. P. 1980. When and how to reproduce: a dilemma for limnetic cyclopoid copepods. Pages 418-426 in W. C. Kerfoot, editor. Evolution and ecology of zooplankton communities. University Press of New England, Hanover, New Hampshire, USA.
Parker, R. A. 1966. The influence of photoperiod on reproduction and molting of Daphnia schodleri Sars. Physiological Zoology 39:266-279.

Sandgren, C. D. 1988. The ecology of chrysophyte flagellates: their growth and perennation strategies as freshwater phytoplankton. Pages 9-104 in C. D. Sangren, editor. Growth and reproductive strategies of freshwater phytoplankton. Cambridge University Press, Cambridge, England.

Silvertown, J. W. 1982. Introduction to plant population ecology. Longman, London, England.

Slobodkin, L. B. 1954. Population dynamics in Daphnia obtusa Kurz. Ecological Monographs 24:69-88.

Snell, T. W. 1986. Effect of temperature, salinity and food level on sexual and asexual reproduction in Brachionus placatilis (Rotifera). Marine Biology (Berlin) 92:157-192.

Spindler, K.-D. 1971. Dormanzauslosung und Dormanzcharakteristika beim Susswassercopepoden Cyclops vicinus. Zoologische Jahrbücher Abteilung für allgemeine Zoologie und Physiologie der Tiere 76:139-151.

Strickler, J. R., and S. Twombly. 1975. Reynolds number, diapause and predatory copepods. Internationale Vereinigung für theoretische und angewandte Limnologie, Verhandlungen 19:2943-2950.

Stross, R. G. 1969. Photoperiod control of diapause in Daphnia. III. Two-stimulus control of long-day, short-day induction. Biological Bulletin (Woods Hole) 137:359-374.

-1987. Photoperiodism and phased growth in Daphnia populations: coactions in perspective. Memorie dell'Istituto Italiano di Idrobiologia 45:413-437.

Stross, R. G., and J. C. Hill. 1965. Diapause induction in Daphnia requires two stimuli. Science 150:1462-1464.

Tauber, M. J., C. A. Tauber, and S. Masaki. 1984. Adaptations to hazardous seasonal conditions: dormancy, migration, and polyphenism. Pages 149-183 in C. B. Huffaker and R. L. Rabb, editors. Ecological entomology. John Wiley, New York, New York, USA.

Tauber, M. J., C. A. Tauber, and S. Masaki. 1986. Seasonal adaptations of insects. Oxford University Press, Oxford, England.

Taylor, F. 1980. Optimal switching to diapause in relation to the onset of winter. Theoretical Population Biology 18: 125-133.

Walton, W. E. 1985. Factors regulating the reproductive phenology of Onychodiaptomus birgei (Copepoda: Calanoida). Limnology and Oceanography 30:167-179.

Watson, N. H. F., and B. N. Smallman. 1971. The role of photoperiod and temperature in the induction and termination of an arrested development in two species of freshwater cyclopoid copepods. Canadian Journal of Zoology 49:855-862. 